\title{
The association of infection and clinical severity in sickle cell anaemia patients
}

\author{
Jose P. Moura Neto ${ }^{\mathrm{a}, \mathrm{b}}$, Isa Menezes Lyra ${ }^{\mathrm{c}}$, Mitermayer G. Reis ${ }^{\mathrm{a}}$, Marilda S. Goncalves ${ }^{\mathrm{a}, \mathrm{b}, *}$ \\ a Centro de Pesquisas Goncalo Moniz, Fundacao Oswaldo Cruz (FIOCRUZ); Rua Waldemar Falcao, 121, Candeal, CEP: 40.296-710. Salvador, Bahia, Brasil \\ b Departamento de Analises Clinicas e Toxicologicas, Faculdade de Farmacia da Universidade Federal da Bahia (UFBA), Av. Barao de Geremoabo, Campus \\ Universitario de Ondina, CEP:40.000-000. Salvador, Bahia, Brasil \\ c Fundacao de Hematologia e Hemoterapia do Estado da Bahia (HEMOBA), Av. Vasco da Gama, s/nº Rio Vermelho, CEP: 40.240-090. Salvador, Bahia, Brasil
}

\section{A R T I C L E I N F O}

\section{Article history:}

Received 12 April 2010

Received in revised form

12 November 2010

Accepted 12 November 2010

Available online 8 January 2011

\section{Keywords:}

Sickle cell anaemia

infection

human T-lymphotropic virus

hepatitis

\begin{abstract}
A B S T R A C T
Sickle cell anaemia (SCA) patients have a high risk of infection. We retrospectively investigated the prevalence of infection among SCA patients from Bahia, Brazil. A total of 1415 SCA patients were studied between 1995 and 2009: 190 (13.4\%) had hepatitis C virus (HCV), 67 (4.7\%) had human T-lymphotropic virus type I (HTLV-I), 44 (3.1\%) had hepatitis B virus (HBV), 40 (2.8\%) had Chagas' disease, 11 (0.8\%) had human immunodeficiency virus (HIV), and $5(0.4 \%)$ had syphilis. Patients with HCV infection had a higher risk of hospitalisation $(\mathrm{OR}=1.52,95 \% \mathrm{Cl}: 1.07-2.17, P=0.020)$, bone disorders $(\mathrm{OR}=1.94,95 \% \mathrm{Cl}: 1.15-3.27$, $P=0.011)$, stroke $(\mathrm{OR}=2.17,95 \% \mathrm{Cl}: 1.12-4.14, P=0.017)$, painful crisis $(\mathrm{OR}=1.61,95 \% \mathrm{Cl}$ : 1.17-2.22, $P=0.004)$ and leg ulcers $(\mathrm{OR}=1.61,95 \% \mathrm{Cl}: 1.04-3.03, P=0.031)$. Patients with $\mathrm{HBV}$ infection had a higher risk for bone disorders ( $\mathrm{OR}=4.90,95 \% \mathrm{Cl}: 2.08-11.54, P<.010)$, stroke (OR=3.01, 95\% Cl: 1.29-6.04, $P=0.007)$, painful crisis $(\mathrm{OR}=3.51,95 \% \mathrm{Cl}: 1.62-7.63$, $P<0.001)$, acute chest syndrome (ACS) (OR=2.66, 95\% Cl: $1.34-5.28, P=0.004)$, leg ulcers $(\mathrm{OR}=6.60,95 \% \mathrm{Cl}: 3.37-12.91, P<.001)$ and vaso-occlusive crisis $(\mathrm{OR}=6.34,95 \% \mathrm{Cl}: 1.96-$ 20.66, $P<0.001)$. Patients with HTLV-I infection had a high risk for bone disorders $(\mathrm{OR}=2.94$, $95 \% \mathrm{Cl}: 1.28-6.74, P=0.011)$, respiratory failure $(\mathrm{OR}=2.66,95 \% \mathrm{Cl}: 1.26-5.51, P=0.012)$, leg ulcers $(\mathrm{OR}=3.27,95 \% \mathrm{Cl}: 1.69-6.11, P<.001)$, painful crisis $(\mathrm{OR}=1.82,95 \% \mathrm{Cl}: 1.07-3.13$, $P=0.025)$ and ACS $(\mathrm{OR}=1.85,95 \% \mathrm{Cl}: 1.10-3.41, P<.047)$. SCA patients with $\mathrm{HCV}$ infection had increased triglycerides and low-density lipoprotein cholesterol $(P=0.036 ; P=0.027)$, iron serum $(P=0.016)$ and ferritin $(P=0.007)$. These results reveal important roles for these infections in SCA patients' clinical outcomes, and studies are warranted to determine the mechanisms utilised by these agents and their involvement in disease severity.
\end{abstract}

(C) 2010 Royal Society of Tropical Medicine and Hygiene. Published by Elsevier Ltd. All rights reserved.

\footnotetext{
* Corresponding author. Laboratorio de Patologia e Biologia Molecular, Centra de Pesquisas Gongalo Moniz, Fundagao Oswaldo Cruz (FIOCRUZ), Salvador, Bahia, Brasil; Rua Valdemar Falcao, 121, Candeal - Salvador-BABrasil.

E-mail address: mari@bahia.fiocruz.br (M.S. Goncalves).
}

\section{Introduction}

Sickle cell anaemia (SCA) is a public health and social problem in Brazil, which has a heterogeneous population due to several waves of immigration, resulting in cultural, socioeconomic and ethnic diversity among its different geographic regions. ${ }^{1}$

Salvador is the largest city in Bahia, a state located in Northeast Brazil, with a population of 2.7 million people. In Salvador, $86 \%$ of the local population is of African origin; 
the frequency of sickle cell heterozygotes ranges from 4.5 to $14.7 \% .^{2}$

Sickle cell anaemia patients have a heterogeneous clinical outcome, presenting acute and chronic complications that are modulated by genetic, environmental and socioeconomic factors. ${ }^{3,4}$ Patients with SCA require frequent blood transfusions and are at high risk for infections such as hepatitis; the frequent transfusions cause an increase in serum iron levels that contribute to the generation of reactive oxygen species (ROS), resulting in SCA severity. ${ }^{5}$ In addition, patients with haemoglobinopathies, bleeding disorders, chronic renal failure on haemodialysis, oncohaematological diseases and acute bleeding are subject to multiple blood transfusions and have an increased risk of transfusion-transmitted infections. ${ }^{6}$

Before 1992, hepatitis C virus (HCV) infection was a major problem among patients with hereditary haemoglobinopathies, however, after 1992, the introduction of serological screening for anti-HCV antibodies at Brazilian blood banks has contributed to better control of HCV infection spread and a significant decrease in this infection. $^{7}$

The human T-lymphotropic virus type I (HTLV-I) was identified in 1978 as the aetiological agent of adult Tcell leukaemia and HTLV-l-associated myelopathy/tropical spastic paraparesis. ${ }^{8}$ Although HTLV-I infection has a high distribution worldwide, the virus is endemic in West and Central Africa, Japan, the Caribbean Basin, South America and isolated areas elsewhere. ${ }^{9}$

Since 1990, several studies have described the occurrence of HTLV-I/II infection in Brazil, and HTLV-I blood donor screening has been mandatory since $1993 .{ }^{10}$ The median seroprevalence in Brazilian blood donors has been estimated to be $0.46 \%$, with a heterogeneous geographical distribution: a lower rate is found in the Southern region, and increasing rates occur towards the Northern and Northeastern regions. Based on data from blood donations and a population-based study, Brazil might have the largest absolute number of HTLV-seropositive individuals in the world, approximately 20-30 times more than the United States or Europe. ${ }^{11}$ In addition to the previous related infections, there have been some reports about the presence of infections prone to be acquired after receiving multiple blood transfusions and their role in the clinical outcome of SCA patients. In this retrospective study, we aimed to investigate the prevalence of transfusiontransmitted infections among SCA patients to establish their possible association with the severity of the disease.

\section{Material and methods}

This study was designed as a retrospective study and included a total of 1415 SCA patients. Data collection covered the years between 1995 and 2009. Participants were patients who attended the outpatient clinic of the Foundation of Haematology and Haemotherapy of Bahia (HEMOBA) in Brazil.

The study was approved by the Goncalo Moniz Research Centre of the Oswaldo Cruz Research Foundation (FIOCRUZ) Human Research Board, and all patients or guardians provided written informed consent in accor- dance with the Declaration of Helsinki of 1975, as revised in 2000. Clinical information was collected from the patients' charts and their physicians.

Patients were considered to have had a blood transfusion if they received a red blood cell (RBC) concentrate or any other blood derivative since the time of registration at HEMOBA or when they reported any transfusions at other health centres.

All haematological and biochemical analyses were performed in the Clinical Analyses Laboratory of the Faculty of Pharmacy/Federal University of Bahia (PHAR-UFBA) and the Pathology and Molecular Biology Laboratory of the Goncalo Moniz Research Center-FIOCRUZ. Serological tests were performed at HEMOBA and confirmed at PHAR-UFBA.

The biochemical analyses of lipid, hepatic and renal metabolism, serum iron and lactate dehydrogenase were measured by immunochemistry assay (A25 system, BioSystems SA, Barcelona, Spain). Serum ferritin was measured by immunoassay using an Access ${ }^{\circledR} 2$ Immunoassay system X2 (Beckman Coulter, Fullerton, CA, USA). C-reactive protein, alpha 1-antitripsin and antistreptolysin-0 were measured by immunochemistry (Immage ${ }^{\circledR} 800$ system, Beckman Coulter).

Haematological analyses were performed using an electronic cell counter Coulter Count T-890 (Coulter Corporation, FL, USA). The haemoglobin ( $\mathrm{Hb}$ ) profile and $\mathrm{HbF}$ levels were investigated by high-performance liquid chromatography (HPLCA/ARIANT I; Bio-Rad, CA, USA).

\section{Statistical analysis}

Baseline characteristics were summarised as means and proportions of selected variables. The distribution of quantitative variables was determined using the Kolmogorov-Smirnov test. Bivariate correlation analyses were conducted to determine any correlations between pairs of variables using Spearman's rho correlation. The parametric ANOVA test confirmed by the Bonferroni post hoc test and the nonparametric Kruskal-Wallis test were used to compare means among two or more groups of interval variables that were normally distributed and not normally distributed, respectively. The interactions between specific categorical clinical variables were tested for significance using a $\chi^{2}$ test corrected by Yates's $\chi^{2}$ and Fisher's exact tests, taking into account the expected frequency in the table cells.

The statistical analysis was developed to test dependent variables associated with hospitalisations, bone disorders, stroke, pain crisis, leg ulcers, respiratory failure and the prevalence of infection. The cause of hospital admission and all demographic, epidemiological and clinical information and management were collected from hospital records. This information included age, gender, genotype, time of hospitalisation, clinical follow-up, use of blood transfusion and pattern of clinical evolution.

The data analysis was performed using EPIinfo 6.04 (CDC, Atlanta, Georgia, USA), the Statistics Data Analysis (STATA) SE 10 (StataCorp, Texas, USA) and GraphPad 7 Prism 5.0 (GraphPad Software, Inc., La Jolla, CA, USA). A P-value of less than 0.05 was considered statistically significant. 
Table 1

Prevalence of different types of infections in 1415 patients with sickle cell anaemia

\begin{tabular}{lll}
\hline Infection & $\begin{array}{l}\text { Infected } \\
n(\%)\end{array}$ & $\begin{array}{l}\text { Non-infected } \\
n(\%)\end{array}$ \\
\hline Chagas' disease & $40(2.8)$ & $1375(97.2)$ \\
Hepatitis B virus & $44(3.1)$ & $1371(96.9)$ \\
Hepatitis C virus & $190(13.4)$ & $1225(86.6)$ \\
Human immunodeficiency virus & $11(0.8)$ & $1404(99.2)$ \\
Human T-lymphotropic virus type I & $67(4.7)$ & $1348(95.3)$ \\
Syphilis & $5(0.4)$ & $1410(99.6)$ \\
\hline
\end{tabular}

\section{Results}

A total of 1415 SCA patients were included in the study: $48.2 \%$ were women, and the mean age was 23.65 years. Haematological analyses showed that 267 (18.9\%) patients had hepatitis B virus (HBV), HCV, human immunodeficiency virus (HIV), Chagas' disease, syphilis and HTLV-I infections (Table 1). The overall rate of infection was $9.75 \%$ (138) for males and 9.11\% (129) for females.

Clinical data analysis between infected and noninfected SCA patient groups revealed statistical significance for acute chest syndrome (OR: $1.76,95 \% \mathrm{Cl}: 1.22-2.53$, $P=0.002$ ), bone disorders (OR: $2.83,95 \% \mathrm{Cl}: 1.60-4.98$, $P<0.001$ ), hospitalization (OR: $1.37,95 \% \mathrm{Cl}$ : 1.02-1.86, $P=0.046$ ), leg ulcers (OR: $2.47,95 \% \mathrm{Cl}: 1.61-3.79, P<0.001$ ), painful crisis (OR: $1.59,95 \% \mathrm{Cl}: 1.20-2.10, P<0.001$ ), stroke
(OR: $1.64,95 \% \mathrm{Cl}: 1.01-2.67, P=0.047$ ) and vaso-occlusive episodes (OR: 1.40, 95\% Cl: 1.04-1.90, $P=0.029$ ) (Table 2).

We found a significant association between the occurrence of $\mathrm{HCV}$ infection and the risk of hospitalisation (OR: 1.52, 95\% Cl: 1.07-2.17, $P=0.020$ ), stroke (OR: $1.94,95 \%$ $\mathrm{Cl}$ : 1.15-3.27, $P=0.011$ ), bone disorders (OR: $2.17,95 \% \mathrm{Cl}$ : 1.12-4.14, $P=0.017$ ), leg ulcers (OR: $1.74,95 \% \mathrm{Cl}: 1.06-2.84$, $P=0.029$ ) and painful crisis (OR: $1.61,95 \% \mathrm{Cl}: 117-2.22$, $P=0.004$ ) (Table 3).

HBV infection was significantly associated with bone disorders (OR: 4.9, 95\% Cl: 2.08-11.54, $P<0.001$ ), stroke (OR: 3.01, 95\% Cl: 1.29-6.04, $P=0.007$ ), painful crisis (OR: 3.51, 95\% Cl: 1.62-7.63, $P<0.001)$, acute chest syndrome (OR: 2.66, 95\% Cl: 1.34-5.28, $P=0.004$ ), leg ulcers (OR: 6.60, 95\% Cl: 3.37-12.91, $P<0.001)$, and vaso-occlusive episodes (OR: 6.34, 95\% Cl: 1.96-20.66, $P<0.001$ ) (Table 3).

Human T-lymphotropic virus type I infection was significantly associated with bone disorders (OR: 2.94, 95\% $\mathrm{Cl}: 1.28-6.74, P=0.011$ ), leg ulcers (OR: $3.27,95 \% \mathrm{Cl}: 1.69-$ 6.11, $P<0.001$ ); painful crisis (OR: $1.82,95 \% \mathrm{Cl}: 1.07-3.13$, $P=0.025$ ), acute chest syndrome (OR: $1.85,95 \% \mathrm{Cl}: 1.10-$ $3.41, P=0.047$ ) and respiratory failure (OR: $2.66,95 \% \mathrm{Cl}$ : 1.26-5.51, $P=0.012$ ). Patients with Chagas' disease had a risk of leg ulcers (OR: 4.47, 95\% Cl: 2.12-9.43, $P<0.001$ ) (Table 3).

We compared haematological and biochemical data between patients who were not infected and were infected with HCV. Compared to non-infected

Table 2

Analysis of medical history and infection among 1415 patients with sickle cell anaemia

\begin{tabular}{|c|c|c|c|c|c|}
\hline Clinical Data & & $\begin{array}{l}\text { Infected } \\
n(\%)\end{array}$ & $\begin{array}{l}\text { Non-infected } \\
n(\%)\end{array}$ & $\mathrm{OR}(\mathrm{Cl})$ & $P$-value \\
\hline Acute chest syndrome & $\begin{array}{l}\text { Yes } \\
\text { No }\end{array}$ & $\begin{array}{l}48(18.3) \\
214\end{array}$ & $\begin{array}{l}125(11.3) \\
980\end{array}$ & $1.76(1.22-2.53)$ & $0.002^{\mathrm{a}}$ \\
\hline Avascular necrosis & $\begin{array}{l}\text { Yes } \\
\text { No }\end{array}$ & $\begin{array}{l}7(2.7) \\
255\end{array}$ & $\begin{array}{l}33(3.0) \\
1072\end{array}$ & $0.89(0.40-2.03)$ & $0.786^{\mathrm{a}}$ \\
\hline Bone disorders & $\begin{array}{l}\text { Yes } \\
\text { No }\end{array}$ & $\begin{array}{l}21(8.0) \\
241\end{array}$ & $\begin{array}{l}33(3.0) \\
1072\end{array}$ & $2.83(1.60-4.98)$ & $<0.001^{\mathrm{a}}$ \\
\hline Bone pain & $\begin{array}{l}\text { Yes } \\
\text { No }\end{array}$ & $\begin{array}{l}28(10.7) \\
234\end{array}$ & $\begin{array}{l}120(10.9) \\
985\end{array}$ & $0.98(0.64-1.51)$ & $0.936^{\mathrm{a}}$ \\
\hline Cholelithiasis & $\begin{array}{l}\text { Yes } \\
\text { No }\end{array}$ & $\begin{array}{l}8(3.1) \\
254\end{array}$ & $\begin{array}{l}24(2.2) \\
1081\end{array}$ & $1.42(0.63-3.20)$ & $0.398^{\mathrm{a}}$ \\
\hline $\begin{array}{l}\text { Dactylitis (hand-foot } \\
\text { syndrome) }\end{array}$ & $\begin{array}{l}\text { Yes } \\
\text { No }\end{array}$ & $\begin{array}{l}9(3.4) \\
253\end{array}$ & $\begin{array}{l}41(3.7) \\
1064\end{array}$ & $0.92(0.44-1.92)$ & $0.831^{\mathrm{a}}$ \\
\hline Hospitalisation & $\begin{array}{l}\text { Yes } \\
\text { No }\end{array}$ & $\begin{array}{l}141(64.4) \\
78\end{array}$ & $\begin{array}{l}495(56.9) \\
374\end{array}$ & $1.37(1.02-1.86)$ & $0.046^{\mathrm{a}}$ \\
\hline Leg ulcer & $\begin{array}{l}\text { Yes } \\
\text { No }\end{array}$ & $\begin{array}{l}36(13.7) \\
226\end{array}$ & $\begin{array}{l}67(6.1) \\
1038\end{array}$ & $2.47(1.61-3.79)$ & $<0.001^{\mathrm{a}}$ \\
\hline Painful crisis & $\begin{array}{l}\text { Yes } \\
\text { No }\end{array}$ & $\begin{array}{l}170(64.9) \\
92\end{array}$ & $\begin{array}{l}594(53.8) \\
511\end{array}$ & $1.59(1.20-2.10)$ & $<0.001$ \\
\hline Renal failure & $\begin{array}{l}\text { Yes } \\
\text { No }\end{array}$ & $\begin{array}{l}10(3.8) \\
252\end{array}$ & $\begin{array}{l}34(3.1) \\
1071\end{array}$ & $1.25(0.61-2.56)$ & $0.543^{\mathrm{a}}$ \\
\hline Renal lithiasis & $\begin{array}{l}\text { Yes } \\
\text { No }\end{array}$ & $\begin{array}{l}6(2.3) \\
256\end{array}$ & $\begin{array}{l}15(1.4) \\
1090\end{array}$ & $1.70(0.65-4.43)$ & $0.275^{\mathrm{a}}$ \\
\hline Retinopathy & $\begin{array}{l}\text { Yes } \\
\text { No }\end{array}$ & $\begin{array}{l}2(0.8) \\
260\end{array}$ & $\begin{array}{l}18(1.6) \\
1087\end{array}$ & $0.47(0.11-2.01)$ & $0.306^{\mathrm{b}}$ \\
\hline $\begin{array}{l}\text { Splenic sequestration } \\
\text { crisis }\end{array}$ & $\begin{array}{l}\text { Yes } \\
\text { No }\end{array}$ & $\begin{array}{l}31(11.8) \\
231\end{array}$ & $\begin{array}{l}144(13.0) \\
961\end{array}$ & $0.89(0.60-1.36)$ & $0.592^{\mathrm{a}}$ \\
\hline Stroke & $\begin{array}{l}\text { Yes } \\
\text { No }\end{array}$ & $\begin{array}{l}24(9.2) \\
238\end{array}$ & $\begin{array}{l}64(5.8) \\
1041\end{array}$ & $1.64(1.01-2.67)$ & $0.047^{\mathrm{a}}$ \\
\hline $\begin{array}{l}\text { Vaso-occlusive } \\
\text { episodes }\end{array}$ & $\begin{array}{l}\text { Yes } \\
\text { No }\end{array}$ & $\begin{array}{l}194(74.0) \\
68\end{array}$ & $\begin{array}{l}741(67.0) \\
364\end{array}$ & $1.40(1.04-1.90)$ & $0.029^{a}$ \\
\hline
\end{tabular}

${ }^{\mathrm{a}} \chi^{2}$ test (Yates's corrected); ${ }^{\mathrm{b}}$ Fisher's exact test

OD: Odds Ratio; $\mathrm{Cl}$ : Confidence Interval 
Table 3

Analysis of medical history and specific infections among 1415 patients with sickle cell anaemia

\begin{tabular}{|c|c|c|c|c|c|}
\hline Clinical Data & & $\begin{array}{l}\text { Infected } \\
n(\%)\end{array}$ & $\begin{array}{l}\text { Non-infected } \\
n(\%)\end{array}$ & $\mathrm{OR}(\mathrm{Cl})$ & $P$-value \\
\hline \multicolumn{6}{|l|}{ Hepatitis C virus } \\
\hline \multirow[t]{2}{*}{ Hospitalisations } & Yes & $106(67.1)$ & $556(57.3)$ & $1.52(1.07-2.17)$ & $0.020^{a}$ \\
\hline & No & 52 & 415 & & \\
\hline \multirow[t]{2}{*}{ Stroke } & Yes & $20(10.6)$ & $70(5.7)$ & $1.94(1.15-3.27)$ & $0.011^{\mathrm{a}}$ \\
\hline & No & 169 & 1149 & & \\
\hline \multirow[t]{2}{*}{ Bone disorders } & Yes & $15(8.1)$ & 45 (3.9) & $2.17(1.12-4.14)$ & $0.017^{\mathrm{a}}$ \\
\hline & No & 171 & 1113 & & \\
\hline \multirow[t]{2}{*}{ Leg ulcer } & Yes & $22(11.6)$ & $86(7.1)$ & $1.74(1.06-2.84)$ & $0.029^{a}$ \\
\hline & No & 167 & 1133 & & \\
\hline \multirow[t]{2}{*}{ Painful crisis } & Yes & $125(66.1)$ & $668(54.8)$ & $1.61(1.17-2.22)$ & $0.004^{\mathrm{a}}$ \\
\hline & No & 64 & 551 & & \\
\hline \multicolumn{6}{|l|}{ Hepatitis B virus } \\
\hline \multirow[t]{2}{*}{ Bone disorders } & Yes & $7(16.3)$ & $52(3.8)$ & $4.9(2.08-11.54)$ & $<0.001^{b}$ \\
\hline & No & 36 & 1311 & & \\
\hline \multirow[t]{2}{*}{ Stroke } & Yes & $7(16.3)$ & $83(6.1)$ & $3.01(1.29-6.04)$ & $0.007^{\mathrm{b}}$ \\
\hline & No & 36 & 1280 & & \\
\hline \multirow[t]{2}{*}{ Painful crisis } & Yes & $35(81.3)$ & $756(55.5)$ & $3.51(1.62-7.63)$ & $<0.001^{\mathrm{a}}$ \\
\hline & No & 8 & 607 & & \\
\hline \multirow[t]{2}{*}{ Acute chest syndrome } & Yes & $12(36.4)$ & $173(12.7)$ & $2.66(1.34-5.28)$ & $0.004^{\mathrm{a}}$ \\
\hline & No & 31 & 1190 & & \\
\hline \multirow[t]{2}{*}{ Leg ulcer } & Yes & $14(32.6)$ & $93(6.8)$ & $6.60(3.37-12.91)$ & $<0.001^{\mathrm{a}}$ \\
\hline & No & 29 & 1270 & & \\
\hline \multirow[t]{2}{*}{ Vaso-occlusive episodes } & Yes & $40(93)$ & $923(67.7)$ & $6.34(1.96-20.66)$ & $<0.001^{\mathrm{b}}$ \\
\hline & No & 03 & 440 & & \\
\hline \multicolumn{6}{|c|}{ Human T-lymphotropic virus type I } \\
\hline \multirow[t]{2}{*}{ Bone disorders } & Yes & $7(10.6)$ & $52(3.9)$ & $2.94(1.28-6.74)$ & $0.011^{\mathrm{b}}$ \\
\hline & No & 59 & 1287 & & \\
\hline \multirow[t]{2}{*}{ Leg ulcer } & Yes & $13(19.7)$ & $95(7.1)$ & $3.27(1.69-6.11)$ & $<0.001^{\mathrm{a}}$ \\
\hline & No & 53 & 1244 & & \\
\hline \multirow[t]{2}{*}{ Painful crisis } & Yes & $46(69.7)$ & $746(55.7)$ & $1.82(1.07-3.13)$ & $0.025^{\mathrm{a}}$ \\
\hline & No & 20 & 593 & & \\
\hline \multirow[t]{2}{*}{ Acute chest syndrome } & Yes & $14(21.2)$ & $170(12.7)$ & $1.85(1.10-3.41)$ & $0.047^{\mathrm{a}}$ \\
\hline & No & 52 & 1169 & & \\
\hline \multirow[t]{2}{*}{ Respiratory failure } & Yes & $11(16.7)$ & $91(6.8)$ & $2.66(1.26-5.51)$ & $0.012^{\mathrm{b}}$ \\
\hline & No & 55 & 1188 & & \\
\hline \multicolumn{6}{|l|}{ Chagas' disease } \\
\hline \multirow[t]{2}{*}{ Leg ulcer } & Yes & $10(25.6)$ & $98(7.2)$ & $4.47(2.12-9.43)$ & $<0.001^{\mathrm{a}}$ \\
\hline & No & 29 & 1270 & & \\
\hline
\end{tabular}

${ }^{\mathrm{a}} \chi^{2}$ test (Yates's corrected); ${ }^{\mathrm{b}}$ Fisher's exact test

OD: Odds Ratio; $\mathrm{Cl}$ : Confidence Interval

patients, infected patients had higher concentrations of low-density lipoprotein cholesterol (LDL-C) $(19.54 \pm 8.34$ vs. $26.39 \pm 14.91 \mathrm{mg} / \mathrm{dl}, P=0.027)$, triglycerides ( $96.78 \pm 40.98$ vs. $132.23 \pm 74.82 \mathrm{mg} / \mathrm{dl}, P=0.002)$, iron serum $(114.75 \pm 103.23$ vs. $218.40 \pm 231.07$ $\mathrm{mcg} / \mathrm{dl}, \quad P=0.009)$ and ferritin (351.25 \pm 371.62 vs. $624.22 \pm 1212.74 \mathrm{ng} / \mathrm{ml}, P=0.007)$. When we compared these same variables between patients not infected and infected with HLTV-I, infected patients had a higher red blood cell count $\left(2.86 \pm 0.66\right.$ vs. $3.10 \pm 0.68 \times 10^{6} / \mathrm{mm}^{3}$,

Table 4

Haematological and biochemical data of 1415 patients with sickle cell anaemia who were infected with HCV or HTLV-I

\begin{tabular}{|c|c|c|c|}
\hline Haematological and biochemical data & $\begin{array}{l}\text { Infected } \\
\text { Mean } \pm \text { SD }\end{array}$ & $\begin{array}{l}\text { Non-infected } \\
\text { Mean } \pm \text { SD }\end{array}$ & $P$-value \\
\hline \multicolumn{4}{|l|}{ Hepatitis C virus (HCV) } \\
\hline LDL-C, mg/dl & $30.67 \pm 26.57$ & $19.54 \pm 8.34$ & $0.027^{\mathrm{a}}$ \\
\hline Triglycerides, mg/dl & $132.23 \pm 74.82$ & $96.78 \pm 40.98$ & $0.002^{\mathrm{b}}$ \\
\hline Iron serum, mcg/dl & $218.40 \pm 231.07$ & $114.75 \pm 103.23$ & $0.009^{\mathrm{b}}$ \\
\hline Ferritin, ng/ml & $624.22 \pm 1212.74$ & $351.25 \pm 371.62$ & $0.007^{\mathrm{b}}$ \\
\hline \multicolumn{4}{|c|}{ Human T-lymphotropic virus type I (HTLV-I) } \\
\hline $\mathrm{RBC}, \times 10^{6} / \mathrm{mm}^{3}$ & $3.10 \pm 0.68$ & $2.86 \pm 0.66$ & $0.029^{\mathrm{a}}$ \\
\hline Haemoglobin, g/dl & $8.38 \pm 1.46$ & $7.78 \pm 1.49$ & $0.008^{a}$ \\
\hline Haematocrit, \% & $26.40 \pm 5.35$ & $24.68 \pm 4.74$ & $0.018^{\mathrm{b}}$ \\
\hline
\end{tabular}

a ANOVA; ' ${ }^{\mathrm{b}}$ Kruskal-Wallis Test

LDL-C: Low-density lipoprotein cholesterol; RBC: Red blood cells 
$P=0.029)$, haemoglobin concentration (7.78 \pm 1.49 vs. $8.38 \pm 1.46 \mathrm{~g} / \mathrm{dl}, P=0.008)$ and haematocrit concentration ( $24.68 \pm 4.74$ vs. $26.40 \pm 5.35 \%, P=0.018)$ (Table 4$)$.

In addition, 45 SCA patients who had concomitant HCV and HTLV-1 infections were statistically more likely to have a history of leg ulcers (OR: 3.71,95\% $\mathrm{Cl}$ : 1.65-8.14, $P<0.001$ ).

\section{Discussion}

The present study retrospectively investigated the prevalence of transfusion-transmitted infections among a group of SCA patients. The most prevalent causes of infection were HCV, HTLV-I, HBV, HIV, Chagas' disease and syphilis.

The prevalence of HCV infection among SCA patients has been previously described to range from $2-30 \%{ }^{7}$ Moreover, the presence of HCV and iron overload is directly related to the number of blood transfusions in SCA patients, contributing to increased iron absorption from chronic haemolysis and direct liver injury due to tissue hypoxia during sickle cell-related vascular occlusion. 5,12 Our results demonstrate that despite the exposure to blood transfusion-transmitted viruses, the majority of SCA patients have normal liver function, as measured by standard biochemical parameters. Interestingly, however, in SCA patients, the plasma haemoglobin liberated from destroyed sickle erythrocytes decreases endothelial nitric oxide (NO) bioavailability, increasing ROS and impairing downstream homeostatic vascular functions of NO, such as inhibition of platelet activation and transcriptional repression of cell adhesion molecules. ${ }^{13,14}$ Our results suggest that increased LDL-C, triglycerides, iron and ferritin concentrations may be related to chronic haemolytic and inflammatory states, as previous described. ${ }^{15,16}$

HBV infection was also associated with an increase in clinical severity among the SCA patients, primarily related to bone disorders and painful crises. There have been some reports related to HBV infection in SCA patients, but the role of the virus in the clinical severity of these patients is unknown. ${ }^{17-19}$

Data are limited about the risk of HTLV-I/II infection in SCA patients. However, a previous report has pointed to the use of blood therapy as a major risk factor in acquired HTLVI infection. ${ }^{20}$ The bones of SCA patients are affected by microinfarction, osteopaenia, osteoporosis, osteomyelitis, and osteonecrosis. ${ }^{21-23}$ The relationship between HTLV-I infection and osteoporosis has been shown by Schachter et al. (2003), who described that changes in the extracellular matrix of neural tissues are important for bone mineral deposition. ${ }^{24}$ According to our results, SCA patients with HTLV-I infection presented a high prevalence of bone disorders, suggesting that HTLV-I contributed to clinical severity. Respiratory failure has been also associated with HTLV-I infection, corroborating our results. ${ }^{25,26}$ In addition, our results suggest an increase in several haematological parameters, such as haemoglobin, haematocrit and red blood cells, which may contribute to worsening of the bone disorder through an increase in blood viscosity secondary to the infection.

We only found an association of Chagas' disease with leg ulcer occurrence in SCA patients, and we did not find any association of syphilis or HIV infection with the clinical outcome of SCA patients, although a few reports have described such associations. ${ }^{27-29}$

The risk of infections from blood transfusions has decreased after the introduction of blood donor screening, mainly for HBV, HBC and HIV. However, additional studies related to these transfusion-transmitted infections and their influence on SCA pathogenesis is of biological interest and may contribute to understanding the mechanisms through which infectious agents interact with SCA, and it will be important to describe these complex networks of associations and their influence on the clinical modulation of the disease.

Authors' contributions: JPMN, IML and MSG conceived and designed the study; JPMN, IML, MGR and MSG performed the collection, analysis and interpretation of the data; JPMN, IML, MGR and MSG drafted the manuscript and critically revised it; all authors read and approved the final manuscript; MSG is the guarantor of the paper.

Acknowledgements: We thank the medical and nursing staff of the two hospitals in which the study was developed, and we also thank the children and parents who gave their informed consent to participate in the study.

Funding: This work was supported by grants from the Brazilian National Council of Research (CNPq) (3065427/2007-5 and 484457/2007-1) (MSG), the Foundation of Research and Extension of Bahia (FAPESB) (1431040053063 and 9073/2007) (MSG), and MCD/CNPq/MS-SCTIE-DECIT (409800/2006-6) (MSG).

Conflicts of interest: None. The sponsors of this study were public or non-profit organisations that support science in general. They had no role in gathering, analysing or interpreting the data.

Ethical approval: The study was approved by the Oswaldo Cruz Research Foundation's Research Ethics Board, and parents or guardians provided written informed consent in accordance with the Declaration of Helsinki.

\section{References}

1. Azevedo ES, Alves AFP, Silva MCBO, Souza MGF, Lima AMVDM, Azevedo W. Distribution of abnormal hemoglobins and glucose-6phosphate dehydrogenase variants in 1200 school children of Bahia, Brazil. Am J Phys Anthropol 1980;53:509-12.

2. Azevedo ES, Silva KM, Da Silva MC, Lima AM, Fortuna CM, Santos MG. Genetic and anthropological studies in the island of Itaparica, Bahia, Brazil. Hum Hered 1981;31:353-7.

3. Ohene-Frempong K, Steinberg MH. Clinical aspects of sickle cell anemia in adults and children. In: Steinberg MH, Forget BG, Higgs DR, Nagel RL, editors. Disorders of hemoglobin: genetics, pathophysiology, and clinical management. New York: Cambridge University Press; 2001. p. 611-70.

4. Steinberg MH. Predicting clinical severity in sickle cell anaemia. Br J Haematol 2005;129:465-81.

5. Fried MW. Management of hepatitis $\mathrm{C}$ in the hemophilia patients. $A m$ J Med 1999;107:85-8.

6. Wallis JP, Wells AW, Matthews JN, Chapman CE. Long-term survival after blood transfusion: a population based study in the North of England. Transfusion 2004;44:102-32. 
7. Hasan MF, Marsh F, Posner G, Bellevue R, Dosik H, Suatengco R, et al. Chronic hepatitis $\mathrm{C}$ in patients with sickle cell disease. Am J Gastroenterol 1996;91:1204-6.

8. Poiesz BJ, Ruscetti FW, Gazdar AF, Bunn PA, Minna JD, Gallo RC. Detection and isolation of type $C$ retrovirus particles from fresh and cultured lymphocytes of a patient with cutaneous T-cell lymphoma. Proc Natl Acad Sci USA 1980;77:7415-9.

9. Vrielink H, Reesink HW. HTLV-I/II prevalence in different geographic location. Transfus Med Rev 2004;18:46-57.

10. de Oliveira MS, Matutes E, Famadas LC, SchulzTF, Calabro ML, Nucci $\mathrm{M}$, et al. Adult T-cell leukaemia/lymphoma in Brazil and its relation to HTLV-I. Lancet 1990;336:987-90.

11. Dourado I, Alcantara LC, Barreto ML, da Gloria Teixeira M, GalvaoCastro B. HTLV-1 in the general population of Salvador, Brazil a city with African ethnic and sociodemographic characteristics. J Acqui Immune Defic Syndr 2003;34:527-31.

12. Lopez L, Lopez P, Arago A, Rodriguez I, Lopez J, Lima E, et al. Risk factors for hepatitis B and C in multi-transfused patients in Uruguay. J Clin Virol 2005;34:69-74.

13. Ault $P$, Jones K. Understanding iron overload: screening, monitoring and caring for patients with transfusion-dependent anemias. Clin J Oncol Nurs 2009;13:511-7.

14. Gladwin MT, Crawford JH, Rakesh PP. Serial review: Biomedical implications for hemoglobin interactions with nitric oxide. The biochemistry of nitric oxide, nitrite, and hemoglobin: role in blood flow regulation. Free Radic Biol Med 2004;6:707-17.

15. Jacobson TA, Miller M, Shaefer EJ. Hypertriglyceridemia and cardiovascular risk reduction. Clin Ther 2007;29:76377.

16. Nofer JR, Kehrel B, Fobker M, Levkau B, Assmann G, von Eckardstein A. HDL and arteriosclerosis: beyond reverse cholesterol transport Atherosclerosis 2002;161:1-16.

17. Le Turdu-Chicot C, Foucan L, Etienne-Julan-Otto M. Viral seroprevalence, transfusion and alloimmunization in adults with sickle cell anemia in Guadeloupe. Transfus Clin Biol 2002;9:11520
18. Pise GA, Vetrichevvel TP, Agarwal KK, Thappa DM. Gianotti-Crost syndrome associated with transfusion acquired hepatitis B virus infection in a patient of sickle cell anemia. Indian J Dermatol Venereol Leprol 2007;73:123-4.

19. Ocak S, Kaya H, Cetin M, Gali E, Ozturk M. Seroprevalence of hepatitis $B$ and hepatitis $C$ in patients with thalassemia and sickle cell anemia in a long-term follow-up. Arch Med Res 2006;37:895-8.

20. Shander A, Sazama K. Clinical consequences of iron overload from chronic red blood cell transfusions, its diagnosis, and its management by chelation therapy. Transfusion 2010;50:1144-55.

21. Miller RG, Segal JB, Ashar BH, Leung S, Ahmed S, Siddique S, et al. High prevalence and correlates of low bone mineral density in young adults with sickle cell disease. Am J Hematol 2006;81:236-41.

22. Sarrai M, Duroseau H, D’Augustine J, Moktan S, Bellevue R. Bone mass density in adults with sickle cell disease. $\mathrm{Br} J$ Haematol 2007; 136:666-72.

23. Almeida A, Roberts I. Bone involvement in sickle cell disease. $\mathrm{Br} \mathrm{J}$ Haematol 2005;29:482-90.

24. Schachter D, Cartier L, Borzutzky A. Osteoporosis in HTLV-lassociated myelopathy/tropical spastic paraparesis (HAM/TSP). Bone 2003;33:192-6.

25. Atsumi E, Yara S, Higa F, Hirata T, Haranaga S, Tateyama M, et al. Influence of human T lymphotropic virus type I infection on the etiology of community-acquired pneumonia. Intern Med 2009;48:959-65.

26. Littleton ET, Man WD, Holton JL, Landon DN, Hanna MG, Polkey Ml, et al. Human T cell leukaemia virus type I associated neuromuscular disease causing respiratory failure. J Neurol Neurosurg Psychiatry 2002;72:650-2.

27. Matsubara LS, Trezza E, Luiz VJ, Krieger H, Machado PE, Padovani CR Hemoglobinopathy $S$ in patients with Chagas' disease. Rev Paul Med 1983;101:14-6.

28. Suchett-Kaye AI. Syphilis, tuberculosis, and sickle-cell anaemia: report of a case. Br J Verier Dis 1948;24:148-50.

29. Barnett CF, Hsue PY, Machado RF. Pulmonary hypertension: an increasingly recognized complication of hereditary hemolytic anemias and HIV infection. JAMA 2008;299:324-31. 